\title{
Database of the Operational Drifter Observations in the Arctic Region
}

\author{
T.M. Bayankina*, S.R. Litvinenko, M.V. Kryl', N.Yu. Yurkevich
}

Marine Hydrophysical Institute, Russian Academy of Sciences, Sevastopol, Russian Federation

*e-mail: bayankina_t@mail.ru

The database (formed in MHI) for 22 drifters deployed in the Arctic region in 2012 - 2016 is represented. The most intensive drifter observations were performed in the Beaufort Sea (the Canada Basin) and in the Central Arctic.

According to the data of temperature-profiling drifters, $\sim 2$ million temperature profiles (including the ones acquired under the ice formations) and $\sim 120.000$ atmospheric pressure measurements were obtained. Total life time of drifters as at August 2016 exceeded 7000 days. General information and technical characteristics of BTC60/GPS/ice/1ps, BTC60/GPS/ice/3ps, SVP-BTC80/GPS temperatureprofiling drifters are given. Features of drifter information primary preparation are enumerated and the technique of database quality assessment is shown. The studies have shown that temperature-profiling data provides the assessment of the ice thickness and its spatial-temporal variability in the region. The results of the experiments carried out in the Arctic reveal the fact that autonomous temperature-profiling "ice" drifters are an effective instrument for studying the Arctic region. According to the results of the experiments carried out in the Arctic and verification of data quality in the formed database, the drifters showed the reliability of operational characteristics. This is confirmed by failure-free operation of IMEI 245950/WMO 48541 drifter which had been performed the measurements during 1.083 days.

The obtained unique long-term series of systematic operational data can be applied for clarifying the concepts of thermal processes variability in the upper ocean layer (including the under-ice one), the dynamics of ice fields and air pressure fields in a wide range of spatial-temporal scales as well as for refining the concept of interaction processes in the Atmosphere - Ice - Ocean system.

Keywords: temperature-profiling drifter, thermo-line, water/ice temperature, temperature profile, ocean upper layer.

DOI: 10.22449/1573-160X-2017-2-65-74

(C) 2017, T.M. Bayankina, S.R. Litvinenko, M.V. Kryl’, N.Yu. Yurkevich

(C) 2017, Physical Oceanography

Introduction. The development of polar and circumpolar regions is one of highpriority problems of modern times, therefore, in recent years the state and public interest in the problems of the Arctic region has increased. The following documents defining the purposes and objectives of the state policy in the Arctic were adopted: in 2008 - "Russian Arctic Strategy for the Period up to 2020 and for a Future Perspective" and in 2013 - "Russian Strategy of the Development of the Arctic Zone and the Provision of National Security until 2020".

The effectiveness of solving the priority problems is determined by the development level of meteorological, hydrological and ice conditions complex observation system in this region. In the world science climatic processes in the Arctic are considered as an indicator of global changes, but the current level of knowledge about the region climate system is insufficient. This is caused by an acute shortage of observational data due to a number of objective reasons: inaccessibility of the region, unfavorable meteorological conditions, limited means of remote sensing due to the presence of predominant cloudiness and ice cover, etc. 
In recent decades drifter technology as a mean of operational contact monitoring has been widely developed within the framework of construction of the World Ocean and near-water atmosphere global observational network. Long-term tests of drifters in arctic conditions became the basis for developing the specialized autonomous measuring tools for the researching the water column, the Arctic ice cover and the methods of their application. Measuring-informational system on the basis of drifter technology as a mean of operational contact monitoring is one of the main segments of global observational network. Wide capabilities of drifter technologies and their economic effectiveness determine the task of creating different specialized drifting platforms adapted to the Arctic region conditions. Solution of this task is closely related to the innovative work of Marine Hydrophysical Institute (MHI) of RAS on drifter technology development [1 - 4].

UpTempO project of the University of Washington [5], aimed at investigation of temperature variation in upper- and under-ice ocean layers (measurement data is available on the website http://psc.apl.washington.edu/UpTempO/Data.php), turned out to be the most large-scale one in application of such means in the region under study.

In 2012 - 2016 hydrometeorological database was formed using the drifter measurements [6].

The structure and technical characteristics of temperature-profiling drifters. In situ measurements were provided by temperature-profiling drifters. Their structure is represented in Fig. 1, their technical characteristics - in Table 1.

Table 1

Technical characteristics of temperature profiling drifters

\begin{tabular}{|c|c|c|c|c|}
\hline \multirow{2}{*}{\multicolumn{2}{|c|}{ Parameters }} & \multicolumn{3}{|c|}{ Drifter type } \\
\hline & & SVP-BTC80/GPS & BTC60/GPS/ice/1ps & BTC60/GPS/ice/3ps \\
\hline \multirow{3}{*}{ Air pressure, hPa } & $R$ & \multirow{3}{*}{\multicolumn{3}{|c|}{$\begin{array}{c}\text { from } 850 \text { to } 1054.6 \\
\pm 2.0 \\
0.1 \\
\end{array}$}} \\
\hline & $\Delta$ & & & \\
\hline & $\mu$ & & & \\
\hline \multirow{3}{*}{$\begin{array}{l}\text { Water temperature, } \\
{ }^{\circ} \mathrm{C}\end{array}$} & $R$ & \multirow[t]{3}{*}{ from minus 20 to 20.94} & \multirow{3}{*}{\multicolumn{2}{|c|}{ from minus 5 to 35.94}} \\
\hline & $\Delta$ & & & \\
\hline & $\mu$ & & & \\
\hline \multirow{3}{*}{ Depth, m } & $R$ & \multirow{3}{*}{\multicolumn{3}{|c|}{$\begin{array}{l}\text { from } 0 \text { to } 100 \\
\pm 0.2 \\
0.01\end{array}$}} \\
\hline & $\Delta$ & & & \\
\hline & $\mu$ & & & \\
\hline \multirow[t]{3}{*}{ Latitude, $^{\circ}$} & $R$ & \multirow{3}{*}{\multicolumn{3}{|c|}{$\begin{array}{c}\text { from minus } 90 \text { to } 90 \\
\pm 0.0005 \\
0.0002 \\
\end{array}$}} \\
\hline & $\Delta$ & & & \\
\hline & $\mu$ & & & \\
\hline \multirow{3}{*}{ Longitude, ${ }^{\circ}$} & $R$ & \multirow{3}{*}{\multicolumn{3}{|c|}{$\begin{array}{c}\text { from } 0 \text { до } 360 \\
\pm 0.0005 \\
0.0002\end{array}$}} \\
\hline & $\Delta$ & & & \\
\hline & $\mu$ & & & \\
\hline \multicolumn{2}{|c|}{$\begin{array}{l}\text { Horizons of temperature } \\
\text { measurement (nominal), } \\
\text { m }\end{array}$} & $\begin{array}{l}0.2 ; 11 ; 13 ; 15 ; 20 ; 25 \\
30 ; 35 ; 40 ; 45 ; 50 ; 55 \\
60 ; 65 ; 70 ; 75 ; 80\end{array}$ & \multicolumn{2}{|c|}{$\begin{array}{l}0.2 ; 2.5 ; 5 ; 7.5 ; 10 ; 12.5 ; 15 ; 17.5 ; 20 ; 25 \\
30 ; 35 ; 40 ; 45 ; 50 ; 55 ; 60\end{array}$} \\
\hline \multicolumn{2}{|c|}{$\begin{array}{l}\text { Horizons of hydrostatic } \\
\text { pressure measurement } \\
\text { (nominal), m }\end{array}$} & (1) & 60 & $20 ; 40 ; 60$ \\
\hline
\end{tabular}

$\mathrm{N}$ o t e. $R$ is a range, $\Delta$ is an error, $\mu$ is resolution. 


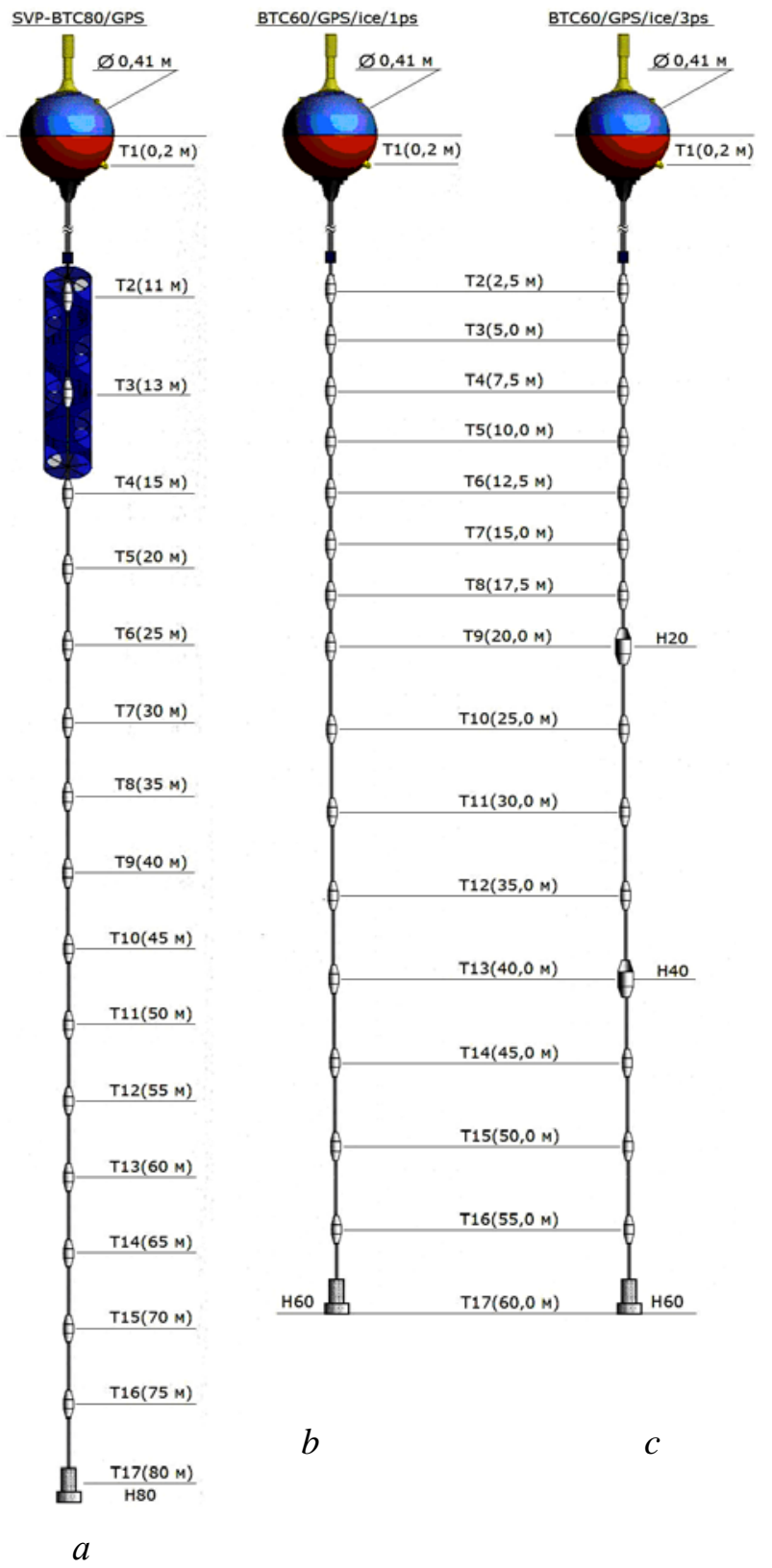

Fig. 1. The structure of MHI temperature-profiling drifters: SVP-BTC80/GPS - $a$; BTC60/GPS/ice/1ps - b; BTC60/GPS/ice/3ps - c

Brief description of measuring tools. SVP-BTC80/GPS drifter is a quasiLangrangian temperature-profiling one with an underwater sail, thermoline down to $80 \mathrm{~m}$ and hydrostatic pressure gauge at the lower end of the temperature line (Fig. 1, a). BTC60/GPS/ice/1ps drifter is a temperature-profiling one with a thermoline down to $60 \mathrm{~m}$ depth and hydrostatic pressure gauge at the lower end of the line (Fig. 1, b). BTC60/GPS/ice/3ps drifter is a temperature-profiling one with a therPHYSICAL OCEANOGRAPHY NO. 22017 
moline down to $60 \mathrm{~m}$ depth and hydrostatic pressure gauges at the lower end of the line as well as at 20 and $40 \mathrm{~m}$ nominal horizons (Fig. 1, c).

The coordinates of drifters are measured by built-in GPS receivers. Measurements of all parameters are carried out at the beginning of each hour. The measurement results are transmitted in messages via Iridium satellite communication system. The delay of message delivery to the user does not exceed 10 min [7 - 10]. It should be pointed out that drifter design allows them to be deployed both on the ice and in the open water with further freezing of their body and a part of temperature line into the ice.

Due to design features of temperature-profiling drifters, only upper horizons are fixed in depth. Actual depths of temperature sensors placed below depend on drift conditions and may differ from the nominal depths (Table 1). One may refine temperature measurement horizons by making adjustments according to thermoline geometry reconstruction algorithm with the known hydrodynamic parameters by the results of hydrostatic pressure measuring with the sensors installed in the thermoline:

$$
H=P_{H} 100 / g \rho,
$$

where $H$ is a depth; $P_{H}$ is a hydrostatic pressure; $g$ is the free fall acceleration; $\rho$ is a density of liquid. Thermoline geometry can be reconstructed using, for instance, the method based on the known results of solving the problem of a homogeneous inextensible thread behavior in a steady flow [11].

Information on the drifters and measurement areas in the Arctic. In 2012 2016 period the most intensive drifter observations were carried out in the Beaufort Sea (Canadian Basin) and in the Central Arctic. The trajectories of buoy drifts and general information on them are given in Fig. 2 and Table 2, respectively.

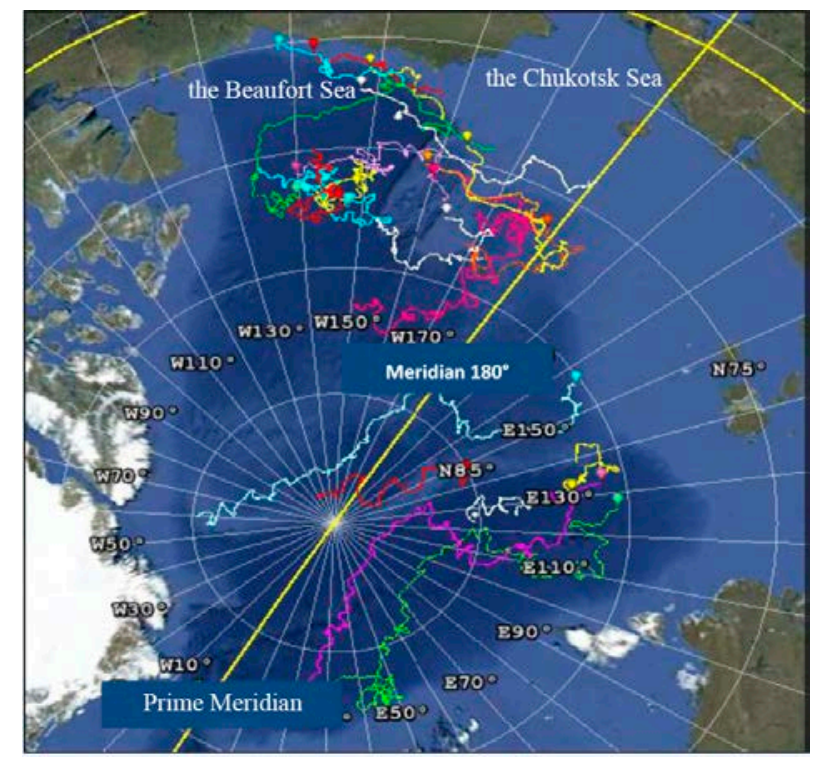

Fig. 2. Trajectories of “ice” temperature-profiling drifters deployed in the Arctic in 2012 - 2016 
Total life time of drifters as at August 2016 exceeded 7000 days. According to the data of temperature-profiling drifters, $\sim 2$ million temperature profiles (including the ones acquired under the ice formations) and $~ 120.000$ atmospheric pressure measurements were obtained. Within the framework of UpTempO project operational systematic monitoring of hydrometeorological parameters was performed using BTC60/GPS/ice/1ps, BTC60/GPS/ice/3ps and SVP-BTC80/GPS-type drifters measurement results of which indicate the possibilities for the ocean upper layer temperature profiling.

Temperature profiling data provides an assessment of temperature vertical distribution in the ocean upper layer near the North Pole, ice thickness and its spatialtemporal variability.

Table 2

General information on the drifters deployed in the Arctic Basin

\begin{tabular}{|c|c|c|c|c|c|}
\hline Buoy identification number & Drifter type & $\begin{array}{l}\text { Thermo- } \\
\text { line } \\
\text { length, } \\
\text { m }\end{array}$ & $\begin{array}{l}\text { The } \\
\text { number } \\
\text { of hori- } \\
\text { zons }\end{array}$ & $\begin{array}{l}\text { De- } \\
\text { ploy- } \\
\text { ment } \\
\text { date }\end{array}$ & $\begin{array}{l}\text { Last date } \\
\text { of meas- } \\
\text { urements }\end{array}$ \\
\hline 240990 & \multirow{7}{*}{ BTC60/GPS/ice/1ps } & \multirow{18}{*}{60} & \multirow{21}{*}{17} & 05.09 .12 & 24.08 .13 \\
\hline 244780 & & & & 31.08 .13 & 11.11.13 \\
\hline IMEI 242970/WMO 48540 & & & & 17.08 .13 & 12.01 .15 \\
\hline IMEI 242840/WMO 48539 & & & & 22.08 .13 & 14.09.14 \\
\hline IMEI 245960/WMO 48542 & & & & 27.08 .13 & 06.02 .15 \\
\hline 244950 & & & & 29.08 .13 & 23.02 .14 \\
\hline IMEI 245950/WMO 48541 & & & & 30.08 .13 & 16.08 .16 \\
\hline IMEI 246740/WMO 25584 & \multirow{11}{*}{ BTC60/GPS/ice/3ps } & & & 30.08 .13 & 14.10 .14 \\
\hline IMEI 246950/WMO 25585 & & & & 03.09.13 & 15.12 .14 \\
\hline IMEI 247800/WMO 25586 & & & & 07.09 .13 & 23.01 .15 \\
\hline IMEI 235160/WMO 48649 & & & & 25.03 .14 & 14.09.14 \\
\hline IMEI 233190/WMO 48648 & & & & 01.04 .14 & 09.09.14 \\
\hline IMEI 238150/WMO 48681 & & & & 13.08.14 & 04.05 .15 \\
\hline IMEI 239180/WMO 48682 & & & & 15.08 .14 & 17.03.15 \\
\hline IMEI 233150/WMO 48679 & & & & 02.09 .14 & 29.07.15 \\
\hline IMEI 236150/WMO 48678 & & & & 06.09.14 & 04.05 .15 \\
\hline IMEI 235320/WMO 48677 & & & & 14.09.14 & 06.10 .14 \\
\hline $\begin{array}{l}\text { IMEI 237170/WMO } 48676 \\
\text { IMEI 233160/WMO } 48680 \\
\end{array}$ & & & & $\begin{array}{l}14.09 .14 \\
02.10 .14 \\
\end{array}$ & $\begin{array}{l}16.10 .14 \\
04.05 .15 \\
\end{array}$ \\
\hline 243770 & \multirow{3}{*}{ SVP-BTC80/GPS } & \multirow{3}{*}{80} & & 03.09 .13 & 12.10 .13 \\
\hline 246990 & & & & 05.09.12 & 10.12.12 \\
\hline 243950 & & & & 09.09 .12 & 13.10 .12 \\
\hline
\end{tabular}

$\mathrm{N}$ o t e. International Mobile Equipment Identity - IMEI; World Meteorological Organization WMO.

The results of arctic experiments reveal the fact that autonomous temperatureprofiling "ice" drifters are an effective instrument for the Arctic region study. The obtained unique long-term series of systematic operational data allow expanding and refining the understanding of the interaction processes in the atmosphere - ice - ocean system [12]. 
Features of initial drifter data preparation for a database formation. Drifter information acquired via GPS global telemetry system sometimes contains failures of different types which may lead to erroneous results. In this regard, in order to create a reliable database interactive programs for identifying and eliminating faulty situations were developed [13].

Filtering by diving measurement results. Initial data on coordinates and sea surface temperature acquired by $S V P-B T C 80 / G P S$-type drifters is subjected to the filtering by the diving. As a result of filtering, only the data from drifting buoys with connected underwater sail was selected. Information on mean duration of drifter float submerged state acquired by the dive measurement channel is the criterion for the underwater sail presence. Continuous zero readings by this channel indicate the breakage of underwater sail. Further movement of the buoy can not be considered as Langrangian particle drift, and its trajectory is mainly determined by the wind effect.

Filtering of rough failures according to the temperature and air pressure measurement results. To filter the failures in data on the surface temperature and its profiles, the program by which the acquired information is processed has been developed. The program allows one interactively detect the failed measurement and delete it. The rejection of water temperature measurement results is carried out on the basis of two consistently applied criteria. The range of physically significant temperatures of the sea upper layer in the drift region is taken as the first criterion, and as the second one the threshold value of the temperature gradient specified by the operator is taken. The samples where temperature values exceed the threshold one are considered to be faulty.

The procedure for filtering the faults in air pressure data is similar to the technique for temperature data filtering. The readings in which the values of pressure gradients exceed $1 \mathrm{hPa} / \mathrm{h}$ are classified as doubtful ones. The solution for such realizations is made by analyzing the monotonicity of the pressure values in subsequent readings or by using the data acquired from other sources in a compatible spatial-temporal scale. After carrying out the abovementioned procedures of primary data filtering and processing at rough failures, the entire drifter measurement array was systematized and composed into a database by the following structure.

The structure of drifter database. Drifter database includes the measurements obtained by 22 drifters (Table 2). For each drifter there is a separate text file with ".txt" extension and the name in ASCII encoding corresponding to the identification number of the drifter. The database is systematized by the types of drifters and consists of "Archive_Arctic" top-level directory within which there are three catalogs: "SVP-BTC80_GPS", "BTC60_GPS_ice_1ps" and "BTC60_GPS_ice_3ps". Within each of these directories the text files with the data of drifters of appropriate type are placed. For instance, the path "Archive_Arctic/SVPBTC60_GPS_ice_1ps/240990.txt" corresponds to BTC60/GPS/ice/1ps type drifter with 240990 identification number.

The content of text files is ordered by lines and columns. "Space" symbol is used as a separating sign. Each line of text file contains the result of one drifter measurement cycle, except for the first line where the names of columns are given. 
The number of columns may vary from 23 to 25 depending on the number of hydrostatic pressure sensors (Table 3).

Table 3

An example of the fragment with 243770.txt file data for-BTC80/GPS-type drifter

\begin{tabular}{l|c|c|c|c|c|c|c|c}
\hline ObsDate & ObsTime & Lat & Lon & BP & T01 & T.. & T17 & H80 \\
\hline 03.09 .2013 & $10: 00$ & 71.4 & -148.9 & 1007.5 & 2.96 & $\ldots$ & -1.28 & 79 \\
03.09 .2013 & $11: 00$ & 71.4 & -148.9 & 1006.6 & 2.88 & $\ldots$ & -1.28 & 81 \\
03.09 .2013 & $12: 00$ & 71.4 & -148.9 & 1005.7 & 2.84 & $\ldots$ & -1.20 & 81 \\
03.09 .2013 & $13: 00$ & 71.4 & -148.9 & 1005.5 & 2.8 & $\ldots$ & -1.32 & 83 \\
\hline
\end{tabular}

The columns of Table 3 contain the following information: ObsDate is a measurement date; ObsTime is a measurement time; Lat is latitude; Lon is a longitude; $B P$ is an air pressure; $T 01 \ldots T 17$ is water (ice) temperature calculated at the nominal depths (Table 1 ); $H 80$ is a depth calculated by the readings of hydrostatic pressure sensor placed at $80 \mathrm{~m}$ nominal horizon (Fig. 1, a).

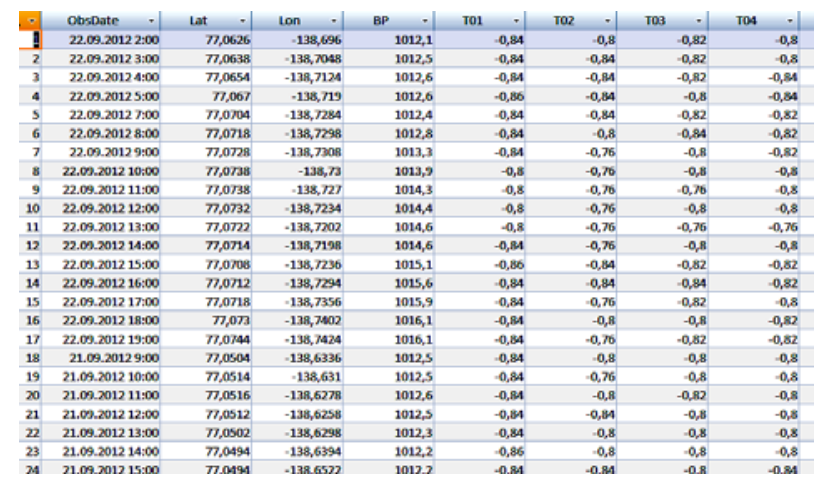

\begin{tabular}{|c|c|c|c|}
\hline ObsDate & & & \\
\hline 24.09.2012 3:00 & 77,1036 & $-138,8378$ & $\begin{array}{l}999.6 \\
998.5\end{array}$ \\
\hline $\begin{array}{l}24.09 .20124: 00 \\
24.09 .20125: 00\end{array}$ & 77.1018 & $\begin{array}{l}-138,8384 \\
-1338512\end{array}$ & 998,5 \\
\hline $24.09 .20126: 00$ & 77,1009 & $-138,8676$ & \\
\hline 24.09 .2012 7:00 & 77,1016 & $-138,8842$ & \\
\hline 24.09 .201278000 & 77,1016 & $\begin{array}{l}-138,88342 \\
-138,8974\end{array}$ & $\begin{array}{l}993,7 \\
994,4\end{array}$ \\
\hline $24.09 .20129: 00$ & 77,1066 & $-138,9066$ & 993,6 \\
\hline $24.09 .201210: 00$ & 77,11 & $-138,9098$ & 992,8 \\
\hline $24.09 .201211: 00$ & 77,1132 & $\begin{array}{l}-138,5098 \\
-138,9062\end{array}$ & 991,7 \\
\hline $24.09 .201212: 00$ & 77,115 & $-138,8976$ & \\
\hline $24.09 .201213: 00$ & 77,1152 & $-138,887$ & 989,9 \\
\hline $24.09 .201214: 00$ & 77,1138 & $\begin{array}{r}-138,8708 \\
-138,878\end{array}$ & 989,3 \\
\hline $24.09 .201215: 00$ & 77,1114 & $-138,8714$ & 989,2 \\
\hline $24.09 .201216: 00$ & 77,1086 & $-138,8716$ & 989,1 \\
\hline $24.09 .201217: 00$ & 77.1066 & $-138,8762$ & 989,3 \\
\hline 24.09 .2012 18:00 & 77,1056 & $-138,8828$ & 989,5 \\
\hline $24.09 .201219: 00$ & 77,106 & $-138,8886$ & 990 \\
\hline $21.09 .201220: 00$ & 77,1074 & $-138,8912$ & 930,7 \\
\hline $24.09 .201221: 00$ & 77,1096 & $-138,839$ & 901,7 \\
\hline $24.09 .201222: 00$ & 77,1 & & 992,7 \\
\hline $24.09 .201223: 00$ & 77,1 & $-138,8668$ & 993,6 \\
\hline $25.09 .20120: 00$ & 77,11 & $-138,8482$ & 994,4 \\
\hline $25.09 .20121: 00$ & & $-138,8266$ & 4,9 \\
\hline $25.09 .20122: 00$ & 77.1108 & $-138,806$ & 5,7 \\
\hline $25.09 .20123: 00$ & 77,107 & $-138,7906$ & 96,3 \\
\hline & & & \\
\hline
\end{tabular}

$b$

Fig. 3. An example of access to the database of operational drifter observations using Microsoft Office Access 2007 DBMS: $a$ - a fragment of database; $b$ - a result of execution of a query on air pressure below $1000 \mathrm{hPa}$ for 240990 drifter by the date for all the years 
For the convenience of the Arctic region database use an automated DBMS (Database managing system) Microsoft office Access 2007 which provides an access to the data of operational drifter observations (Fig. 3, $a$ ) and allows one automatically select data on demand and find relation between it (Fig. $3, b$ ) was developed [14, 15].

The assessment of the drifter database quality was performed in two stages. At the first stage rough failures were excluded from the data arrays according to criteria of drifter diving measurement, the data of air pressure and water temperature using the programmatic method.

The second stage of verification consisted in identification of single ejection in the arrays of hydrometeorological data at all nominal horizons. For each drifter, The maps of trajectories, graphs for atmospheric pressure and surface temperature of water/ice were plotted at all horizons for each drifter. If single outliers in the data were within the array or there were acceptable ranges $(R)$ by hydrometeorological parameters (Table 1), then these data were considered erroneous and (according to WMO requirements) were replaced by 999 which means no data. As an example, in Fig. 4 time series of water temperature at $7.5 \mathrm{~m}$ nominal horizon according to $T 04$ sensor of IMEI242840 drifter is shown in blue. It can be seen that on May 19 and 28, 2014 the water temperature outliers up to $-20{ }^{\circ} \mathrm{C}$ (circled) are observed. Time series of data after excluding faulty samples are given below in red.

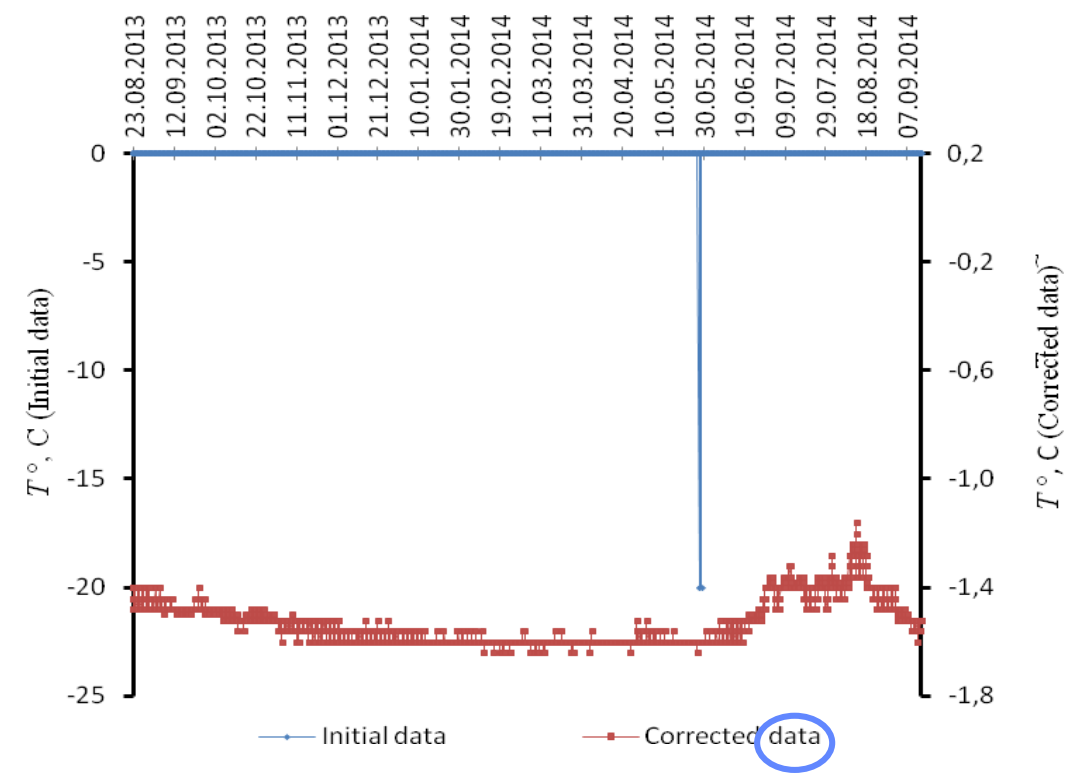

Fig. 4. An example of verification of water temperature measurement (performed by IMEI242840/WMO 48539 drifter) results

According to the results carried out in the Arctic and verification of data quality in the formed database, the drifters developed in MHI proved the reliability of their operational characteristics. This is confirmed, for instance, by long-term operation of IMEI245950/WMO48541 drifter which had been performed the measure- 
ments for almost three years (1082 days). The trajectory of this drifter that was placed on August 30, 2013 in the Arctic Ocean - 1, and on August 16, 2016 stopped transmitting the data -2 is shown in Fig. 5. A long period of operation of the mentioned drifter in the Arctic region provides reliable assessment of thermal processes dynamics in the Arctic Ocean under-ice layer in a wide range of spatialtemporal scales [5].

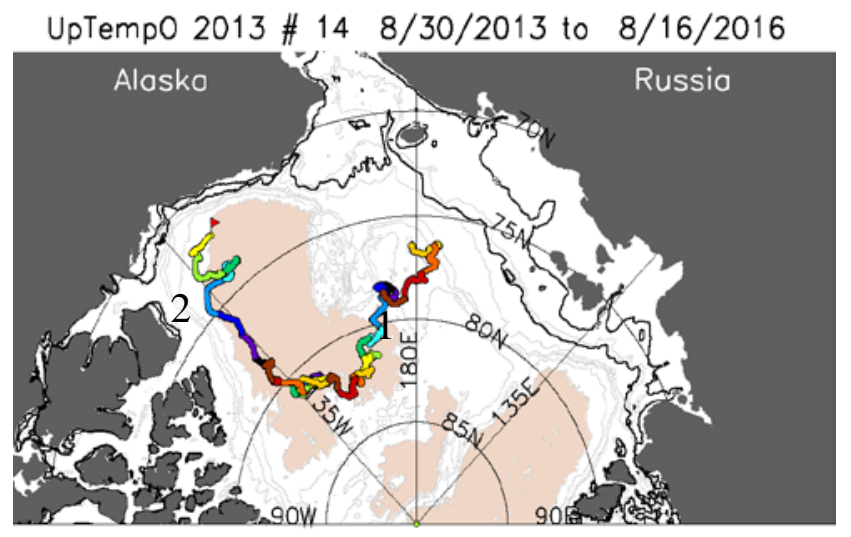

Fig. 5. The studies of the Arctic region performed by IMEI245950/WMO48541 drifter during 30.08.2013 - 16.08.2016 period. The drifter trajectory is given according to the data [5]

Conclusions. The database for operational drifter monitoring of thermal processes in the upper (including under-ice) layer, dynamics of ice and air pressure field in the Arctic region has been formed. The results of the experiments can be the basis for the creation of a reliable and economical observation system using temperature-profiling drifters.

Acknowledgements. The study is carried out within the framework of the State Order No. 0827-2014-0011 "The research of regularities of marine environment condition changes on the basis of operational observations and the data of marine area condition nowcast, forecast and reanalysis system" ("Operative oceanography" code).

\section{REFERENCES}

1. Tolstosheev, A.P., Lunev, E.G., Korotaev, G.K. and Motyzhev, S.V, 2004. Termoprofiliruyushchiy Dreyfuyushchiy Buy [Temperature-Profiling Drifting Buoy]. In: Ekologicheskaya Bezopasnost Pribrezhnoy i Shel'fovoy Zon i Kompleksnoe Ispol'zovanie Resursov Shel'fa [Ecological Safety of Coastal and Shelf Zones and Complex Use of Shelf Resources]. Sevastopol: MGI NANU. Iss. 11, pp. 143-154 (in Russian).

2. Tolstosheev, A.P., Lunev, E.G. and Motyzhev, V.S., 2008. Development of Means and Methods of Drifter Technology Applied to the Problem of the Black Sea Research. Oceanology, [ejournal] 48(1), pp. 138-146. doi: 10.1007/s11491-008-1016-4

3. Tolstosheev, A.P., Lunev, E.G. and Motyzhev, S.V., 2008. Issledovanie Verkhnego Sloya Chernogo Morya s Pomoshch'yu Termoprofiliruyushchikh Dreyfuyushchikh Buev [The Study of the Black Sea Upper Layer Using the Temperature-Profiling Drifting Buoys]. In: Ekologicheskaya Bezopasnost' Pribrezhnoy I Shel'fovoy Zon i Kompleksnoe Ispol'zovanie Resursov Shel'fa [Ecological Safety of Coastal and Shelf Zones and Complex Use of Shelf Resources]. Sevastopol: MGI NANU. Iss. 16, pp. 116-123 (in Russian). 
4. Tolstosheev, A.P., 2011. Ispol'zovanie Termoprofiliruyushchikh Dreyfuyushchikh Buev dlya Izucheniya Verkhnego Sloya Chernogo Morya [Application of Temperature-Profiling Drifting Buoys for the Study of the Black Sea Upper Layer]. In: Ekologicheskaya Bezopasnost' Pribrezhnoy $i$ Shel'fovoy Zon i Kompleksnoe Ispol'zovanie Resursov Shel'fa [Ecological Safety of Coastal and Shelf Zones and Complex Use of Shelf Resources]. Sevastopol: MGI NANU. Iss. 24, pp. 273-278 (in Russian).

5. UpTempo Buoy Project Web Site. [online] Available at: http://psc.apl.washington.edu/UpTempO/ [Accessed: 20 November 2016].

6. Motyzhev, S.V., Tolstosheev, A.P. and Lunev, E.G. [et al.]. Baza Dannykh Operativnykh Drifternykh Nablyudeniy po Regionu Arktiki [Database of Operational Drifter Observations in the Arctic Region]. Certificate of State Registration of Database no. 2016620880, Morskoy Gidrofizicheskiy Institut RAN, Date of State Registration in the Database State Register 28 June 2016.

7. Lunev, E.G., 2003. Avtomaticheskaya Korrektsiya Pogreshnosti Izmeriteley Atmosfernogo Davleniya dlya SVP-B Drifterov [Automatic Correction of Errors of Measuring Atmospheric Pressure for SVP-B Drifters]. In: Vestnik SevGTU [Bulletin of SevGTU]. Sevastopol: SevNTU Publ. Iss. 47, Informatika, elektronika, svyaz', pp. 204-208 (in Russian).

8. Tolstosheev, A.P., 2007. Metod Vosstanovleniya Traektoriy Avtonomnykh Dreyfuyushchikh Buev [A method for Reconstruction of Autonomous Drifting Buoy Trajectories]. In: Ekologicheskaya Bezopasnost' Pribrezhnoy i Shel'fovoy Zon i Kompleksnoe Ispol'zovanie Resursov Shel'fa [Ecological Safety of Coastal and Shelf Zones and Complex Use of Shelf Resources]. Sevastopol: MGI NANU. Iss. 15, pp. 392-396 (in Russian).

9. Motyzhev, S.V., Lunev, E.G. and Tolstosheev, A.P., 2011. Razvitie Drifternoy Tekhnologii i Ikh Vnedrenie v Praktiku Okeanograficheskikh Nablyudeniy v Chernom More i Mirovom Okeane [The Development of Drifter Technologies and Their Implementation into the Practice of Oceanographic Observations in the Black Sea and the World Ocean]. In: Ekologicheskaya Bezopasnost' Pribrezhnoy i Shel'fovoy Zon i Kompleksnoe Ispol'zovanie Resursov Shel'fa [Ecological Safety of Coastal and Shelf Zones and Complex Use of Shelf Resources]. Sevastopol: MGI NANU. Iss. 24, pp. 259-272. Available at: https://elibrary.ru/item.asp?id=26300476 [Accessed 2 November 2016] (in Russian).

10. Motyzhev, S., Lunev, E. and Tolstosheev, A., 2012. Increasing of Effectiveness and Reliability of Data from Drifting Buoys. In: DBCP Technical Document No. 45. Proceedings at the DBCP Scientific and Technical Workshop. Fremantle, Australia, 2 October 2012. WMO-IOC Data Buoy Cooperation Panel, 23 p. Available at: https://library.wmo.int/pmb_ged/dbcptd_45_en/presentations/DBCP-28-Wrk-11-Motyzev-Effectiveness-Article.pdf [Accessed 5 November 2016].

11. Merkin, D.R., 1980. Vvedenie v Mekhaniku Gibkoy Niti [Introduction to the Flexible Thread Mechanics]. Moscow: Nauka Publ., 240 p. (in Russian).

12. Motyzhev, S.V., Lunev, E.G., Tolstosheev, A.P. and Bykov, E.M., 2016. Opyt Primeneniya Termoprofiliruyushchikh Drifterov dlya Issledovaniy Arkticheskogo Regiona Mirovogo Okeana [Experience of Using the Thermal Profiling Drifters to Study the Arctic Region of the Ocean]. Arktika: Ekologiya i Ekonomika, (1), pp. 38-45. Available at: http://arcticaac.ru/docs/1(21)2016/038_045_ARCTICA_1_2016.pdf [Accessed 1 November 2016] (in Russian).

13. Ratner, Yu.B., Tolstosheev, A.P., Kholod, A.L. and Motyzhev, S.V., 2009. Creation of the Database of Monitoring of the Black Sea by Using Drifters. Physical Oceanography, [ejournal] 19(3), pp. 170-185. doi:10.1007/s11110-009-9043-9

14. Paklina, V.M. and Paklina, E.M., 2009. Sozdanie Baz Dannykh v Microsoft ACCESS 2007 [Creation of Databases in Microsoft ACCESS 2007]. Ekaterinburg: GOU VPO UGTU-UPI, 40 p. Available at: http://pedcollege.com/wp-content/uploads/2012/11/16_Access_2007.pdf [Accessed 3 November 2016] (in Russian).

15. Free-office.net. [online] Available at: http: //free-office.net/microsoft-access/31-microsoft-access2007.html [Accessed 4 November 2016]. 